\title{
Modern Navigation System DGPS as a Function of Saving in Agriculture
}

\author{
Mladen JURIŠIĆ, Ivan PLAŠČAK, Domagoj ZIMMER, Željko BARAČ, Irena RAPČAN
}

\begin{abstract}
This research was based on the exploitational analysis of the navigational devices by a family farm from eastern part of Croatia - location Bilje. The research developed into the assessment of the total overlapping surface which ocurred during with and without navigation. The difference between estimated surfaces of overlaps formulates total reduction of the surface of an overlap. Calculations confirm that this farm managed to decrease the surface of the overlaps from 364 ha to much smaller number of 152 ha just by using navigation, which totals to a difference of 211,74 ha $(58,24 \%)$. The farm was able to process an area of 5364,06 ha in all operations, where 364,06 ha was lost on overlapping without the use of navigation. Larger manufacturers have better possibility and the need to install new technologies to a greater extent, where savings are in much bigger numbers. In order to make proper use of a navigational system, it is necessary to invest additional resources so that the system can be equipped with an automatic section control. The automatic section control demands additional investments in devices that control the work of the section.
\end{abstract}

Keywords: agriculture; DGPS; navigation; production plants - farming; rationalization - savings

\section{INTRODUCTION}

In the future, almost every farm will be enabled the use of information technology such as the global positioning system (GPS), geographic information system (GIS) and the technology of precision agriculture and navigational systems. The main goal of the use of geoinformation technologies in agriculture is a rational management of natural resources and the decrease in resource losses caused by inadequate management [1-4]. Large and constant need for food conditioned the progressive development of agricultural production technologies, which in turn helped develop more resources for mechanized agriculture [5, 6]. Today, farmers need to make a profit in order to keep the production business afloat and manage to save their own resources and assets [7].

According to [8] some advanced farmers in highly developed agricultural countries are already implementing some of the technological possiblities of precise agriculture. The same author also claims that in France, 10 $\%$ of the farmers use some kind of precise agriculture systems. A few big agricultural companies in Croatia follow the modern trends of applying highly developed technologies of production using the most advanced machinery [9]. The manufacturers of the navigational devices, used in agriculture, point out how these kinds of systems are able to decrease the consumption of row materials [10] and the amount of overlapping that happens during work in the field. According to a research carried out by [11] applying the most advanced technical systems for satellite navigation and automatic control on agricultural production surfaces of an agricultural corporation achieved a higher amount of savings, mostly by a more precise integration of passages. Taking into consideration all agricultural operations during the season, the research showed a saving of $301980 €$ on an 18959 ha agricultural surface. Hypothesis of the conducted study is that using of modern navigation systems significant savings are achieved in application of all resources in agrotechnology. These savings are reflected in the reduction in the total area of overlap, reducing the total cost of the final product etc. Gathering data from exploitational analysis of the use of the navigational device acquire the advantages and ways of saving on agricultural production surfaces of the farms.

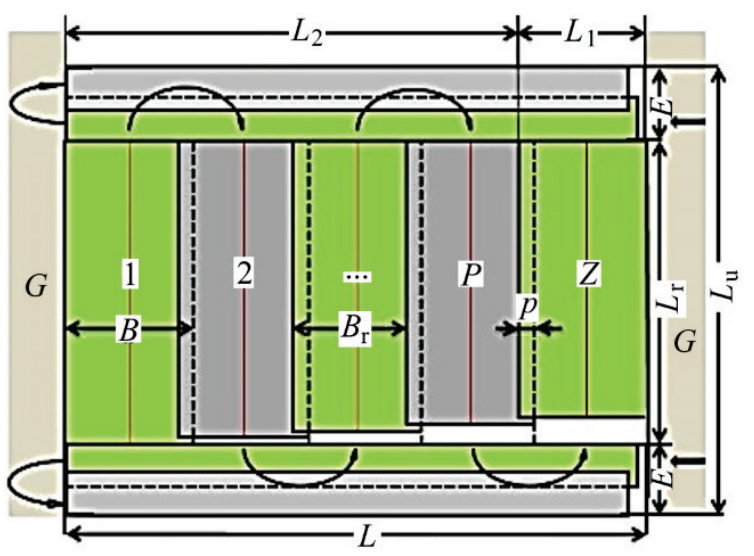

Figure $1 \mathrm{~A}$ schematic display of an average parcel with measuring units 1 and 2 - first and second passage, $P$ - the passage next to the last one, $Z$ - the last passage, $B$ - structural procedure of a machine $(\mathrm{m}), B_{\mathrm{r}}$ - exploitational procedure of a machine $(\mathrm{m}), G$ - borders of the field, $L_{2}$ - width of the $N^{\prime}$ number of passages (m), $L$ - width of an average parcel (m), $L_{1}$ - width of the remaining processable area of the field $(\mathrm{m}), p$ - mean value of an overlap at passage imbedding $(\mathrm{m}), E$ - width of headland $(\mathrm{m}), L_{\mathrm{u}}\left(L_{\mathrm{u}}=L_{\mathrm{r}}+2 E\right)$ - total lenght of an average parcel $(\mathrm{m}), L_{\mathrm{r}}$ - length of a parcel without headlands $(\mathrm{m})$

\section{MATERIALS AND METHODS}

The research was based on the exploitational analysis of the navigational devices by a family farm from eastern part of Croatia- location Bilje. Surveying and work analysis of the navigation device were conducted in a commercial yard and on the production areas of the observed farm. Through the survey of the owner and the operator, the following data was collected: total size of agricultural surfaces and total number of parcels, the amount and state of mechanization, size of structural machine procedures used in the research, a share of certain agricultural crops in total production, means of producing certain crops i.e. the number of use of every individual machine of a certain crop, issues of produce at certain market conditions, implementation of a certain measure of precise agriculture, regular analysis of soil, advantages and flaws of the use of a navigational receiver. The research delved into the assessment of the total overlapping surface which ocurred during the driving machine with and without 
navigation. The difference between the estimated surfaces of overlaps formulates the total reduction of the surface of an overlap. The farm has at its disposal 500 hectares of land, which contain 150 parcels. Being that it is impossible to properly conduct measurements of lenght and width, i.e. the surface and the exact shape of every individual parcel under these circumstances. In the research was the amount of the overlap of the computer on the surface of an average square-shaped parcel with an area of 3,33 ha. Tab. 1 exhibits the width values of the exploitational work procedures of the overlap, which resulted from the use of a structural procedure that had a mean value of $93 \%$. The calculation of the surface of the overlap in observed machines that deal with soil processing and cultivation such as disc harrow, spike harrow etc. is based on the calculation of the required number of passages needed for the processing of an average parcel and the calculation of individual areas and the total surface of an overlap on an average parcel. Fig. 1 shows a parcel with all the labels of measured values which are supposed to make it easier to follow the calculation procedure.

Table 1 Review of utilization of the work procedure performed on machines of the farm

\begin{tabular}{|c|c|c|c|c|c|c|}
\hline $\begin{array}{l}\text { Utilization of the } \\
\text { procedure } 93 \%\end{array}$ & 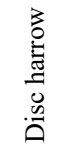 & $\begin{array}{l}\dot{0} \\
\stackrel{0}{0} \\
\delta \\
0 \\
0 \\
\overline{0} \\
\ddot{0}\end{array}$ & 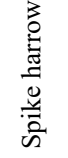 & 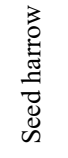 & 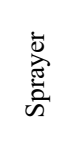 & 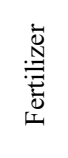 \\
\hline $\begin{array}{c}\text { Structural procedure, } \\
B(\mathrm{~m})\end{array}$ & 4 & 3 & 4 & 5,60 & 18 & 18 \\
\hline $\begin{array}{c}\text { Exploitational procedure, } \\
B_{\mathrm{r}}(\mathrm{m})\end{array}$ & 3,72 & 2,79 & 3,72 & 5,21 & 16,74 & 16,74 \\
\hline $\begin{array}{l}\text { Width of an overlap, } \\
\qquad p(\mathrm{~m})\end{array}$ & 0,28 & 0,21 & 0,28 & 0,39 & 1,26 & 1,26 \\
\hline
\end{tabular}

\subsection{The Procedure of the Manual Calculation of an Overlap - Calculation of the Required Number of Passages for the Process of an Average Parcel}

Required number of passages with a linking machine for the process of an average parcel equals:

$$
N=\frac{L}{B_{\mathrm{r}}}
$$

It is necessary to subtract one passage from the total calculated number of passages $N$ since the width of the last passage of the $Z$ field equals $B$, i.e. there is an overlap between $Z$ and $P$, whose width differs in a certain value from the average width of all previous overlaps by the formula:

$$
N^{\prime}=N-1
$$

$N$ has an equal mean value of an overlap $p$ between all passages therefore the total width of the passages is marked with $L_{2}$ and totals:

$$
L_{2}=N^{\prime} \times B_{\mathrm{r}}
$$

Subtracting the total passage width $N^{\prime}$ from the total field width $L$ calculates the $L_{1}$ value, that is, the value of the width of the remaining field area left for processing, i.e. the value that shows how much space is left for embedding the last passage:

$L_{1}=L-L_{2}$

It is important to note that three instances can appear in regard to the $L_{1}$ and $B$ values (structural procedure of the machine - last passage) at exploitation:

$L_{1}>B$

If $L_{1}$ is bigger than the structural procedure of the machine $B$ during the embedding of the last and next to last passages, a smaller than the avergae overlap width will occur between all previous passages. This happens because the operator of the machine aligns it with the field borders and then moves away from the passage next to last for the amount of difference between $L_{1}$ width and width of the structural procedure of the machine $B$. This procedure decreases the size of the overlap for that amount of difference. The size of the p' overlap between the last and next to last is then calculated as: the amount of difference between $L_{1}$ and $B$ width is marked with the letter $x$ and equals to:

$x=L_{1}-B$

Since the operator has more room for embedding passages from the structural procedure aggregates, he will align the machine with the field border, which results in decrease of overlap for $x$ amount. Overlap $p^{\prime}$ between $P$ and $Z$ is therefore:

$$
\begin{aligned}
& p^{\prime}=p-x \\
& -L_{1}=B
\end{aligned}
$$

average width of an overlap is equal between all passages,

$$
\begin{aligned}
& p^{\prime}=p \\
& x=0 \\
& -L_{1}<B
\end{aligned}
$$

If $L_{1}$ is smaller than the structural procedure of the machine $B$ during the embedding of the last and next to the last passsages, there will be a bigger-than- average width of an overlap between all previous passages. This occurs due to the alignment of the machine by the operator with the field borders, but because of the lack of width necessary to embed the last passage, he has to aditionally overlap the last passage. The difference of value between $B$ and $L_{1}$ widths is marked with $x^{\prime}$ and equals:

$x^{\prime}=B-L_{1}$

Since the operator has 'too little' space for embedding the last passage, that is, the remaining field width $L_{1}$ is smaller than the structural procedure of aggregate $B$, the operator will align with the field border, but he will additionally overlap the last passage which results in increase of the 
overlap $p$ for $x^{\prime}$ amount. The overlap $p^{\prime}$ between $P$ and $Z$ equals to:

$$
p^{\prime}=p+x^{\prime}
$$

In machines which apply a certain amount of substances directly to the soil or plants, like sprinklers and mineral fertilizers, there is a certain possibility of utilizing a certain part of the work procedure $B^{\prime}$ during the application of substances in the last passage. The operator will estimate or measure out the width of the necessary part, on which mineral manure or a protective agent will be applied, and will according to this data utilize the specific work procedure $B^{\prime}$. In centrifugal spreaders of fertilizer $B^{\prime}$ can amount to a half of the structural work procedure $B$, which results in an averagely larger amount of overlaps $p^{\prime}$ than in sprinklers in which the required width of the work procedure $B^{\prime}$ can be better adjusted to the necessary width of the remaining part of the field which requires treatment $L_{\text {pd. }}$. During the work of a sprinkler, the operator can turn off a portion of unnecessary sections at the last passage. The width of a $p^{\prime \prime}$ overlap will occur in sprinklers too, since the operator has to secure a minimal value of the work procedure $B^{\prime}$ which in turn secures the treatment of the width of the remaining part of the field ready for processing $L_{\mathrm{pd}}$ :

$$
L_{\mathrm{pd}}=L_{1}-p
$$

The overlap that occurs is marked as $p^{\prime \prime}$ and is calculated in the following way:

$$
p^{\prime \prime}=B^{\prime}-L_{\mathrm{pd}}
$$

\subsection{Calculation of Specific Surfaces and the Total Surface of Overlaps on an Average Parcel}

The total surface of an overlap on an average parcel $S_{\mathrm{pp}}$ during agricultural operations with a specific linking machine consists of the following overlap surfaces:

1) Surface of $S_{N^{\prime}-1}$ overlaps (if the number of passages required for field processing is $N=49$, then $N^{\prime}$, according to previous calculations, equals 48 passages with a specific value of overlaps which occurs between those passages. Still, it is important to notice that 48 passagess result in 47 overlaps because the first passage does not overlap at all).

$S_{N^{\prime}-1}=\left(N^{\prime}-1\right) \cdot p \cdot L_{\mathrm{r}}$

2) Surfaces of the $S_{p^{\prime}}$ overlap that occured during the embedding of the last and next to last passages during which a $p^{\prime}$ value appears. The size of the $p^{\prime}$ overlap can be equal to all other overlap sizes, bigger than $p$ or smaller $\left(p^{\prime}>p, p^{\prime}<p, p^{\prime}=p\right)$. Total surface of $S_{p^{\prime}}$ with an overlap $p^{\prime}$ width equals:

$S_{p^{\prime}}=p^{\prime} \cdot L_{\mathrm{r}}$

3) Surface of overlaps that occur during headland processing, $S_{\text {u. }}$ It has been assumed during operation of the machine that the bandwidth of the headland suffices for aggregate rotation. This bandwidth equals the width of two overlaps but from every end of the field. The surface of an overlap that occurs during headland processing $S_{\mathrm{u}}$ equals:

$S_{\mathrm{u}}=2 p \cdot L$

Calculation of total overlap surface on an average parcel $S_{\mathrm{pp}}$ can be shown in the following manner:

$S_{\mathrm{pp}}=S_{N^{\prime}-1}+S_{p^{\prime}}+S_{\mathrm{u}}$

It is important to note that the calculation of total overlap surface $S_{\mathrm{pp}}$ during the work of a sprinkler and a fertilizer does not add overlap surface values which occur during headland processing individually, since the total value of passage length is used in the calculation of overlap surface $S_{N^{\prime}-1}$ i $S_{p^{\prime \prime}}$ i.e.:

$L_{\mathrm{r}}=L_{\mathrm{u}}$

Total overlap surface during the work of a sprayer and fertilizer consists of: overlap surface $S_{N^{\prime}-1}$, made during the overlapping of $N^{\prime}-1$ number of passages which amounts to:

$S_{N^{\prime}-1}=\left(N^{\prime}-1\right) \cdot p \cdot L_{\mathrm{r}}=(9 \times 1,26 \mathrm{~m}) \times L_{\mathrm{u}}$

Overlap surfaces $S_{p^{\prime \prime}}$ that ocurred at the last passage, wherein the overlap $p^{\prime \prime}$ value emerges

$S_{p^{\prime \prime}}=$ width overlap $p^{\prime \prime} \times L_{\mathrm{u}}$

Total surface of $S_{\mathrm{pp}}$ overlap was calculated by adding the overlap surface $S_{N^{\prime}-1}$ and $S_{p^{\prime \prime}}$. Total surface of an overlap during the work of a sprayer on parcel amounts to:

$S_{\mathrm{pp}}=S_{N^{\prime}-1}+S_{p^{\prime \prime}}$

\subsection{Process of Overlap Calculation - Assistance with the Management of a Navigational Device}

The navigational device Farmnavigator 67 , with the use of a currently installed antenna, enables precise execution of work ranging from 10-40 cm, depending on the conditions of the satellite signal reception. In excellent conditions of the signal reception, i.e. DOP (dilution of precision) value that does not cross 2 , a very good average level of work precision is enabled. A specific level of precision is incorporated into the calculation, which secures an overlap size of $20 \mathrm{~cm}$ during all operations. During the research, the work of devices on the agricultural surfaces of the farm was observed where there were similar overlap values noticed, with a few exceptions. The calculation of overlap surfaces during manual handling of a driving machine with the help of a navigational device, encompassed the calculation of overlaps that occur during this kind of operation: disc harrows, spike harrows, seed harrows, soil looseners, sprinklers and fertilizers. 


\subsection{Satellite Guidance and Improvement of Signal Reception Quality}

The reception of correctional signals is of significant importance in agriculture during execution of various agricultural operations, which demand a high level of precision. Differential GPS enables a drastic precision improvement of GPS receivers. In most cases in agriculture, the RTK (Real time Kinetic) system is used. By utilizing the RTK system, it is possible to acquire a precision of just mere centimeters. The majority of today's agricultural navigational devices have the ability to upgrade their system.

Table 2 Utilization of structural procedures of machines during operations carried out with the help of a navigational device

\begin{tabular}{|c|c|c|c|c|c|c|}
\hline & 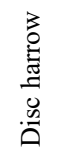 & 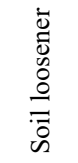 & 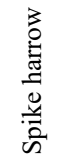 & 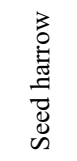 & 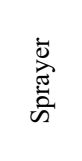 & 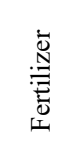 \\
\hline $\begin{array}{c}\text { Structural procedure, } \\
B(\mathrm{~m})\end{array}$ & 4 & 3 & 4 & 5,6 & 18 & 18 \\
\hline $\begin{array}{c}\text { Exploitational } \\
\text { procedure, } B_{\mathrm{r}}(\mathrm{m})\end{array}$ & 3,80 & 2,80 & 3,80 & 5,4 & 17,80 & 17,80 \\
\hline $\begin{array}{c}\text { Width of an overlap, } \\
p(\mathrm{~m})\end{array}$ & 0,20 & 0,20 & 0,20 & 0,20 & 0,20 & 0,20 \\
\hline $\begin{array}{l}\text { Utilization of the } \\
\text { procedure, }(\%)\end{array}$ & 95 & 93,33 & 95 & 96,43 & 98,89 & 98,89 \\
\hline
\end{tabular}

These kinds of devices are installed on the steering wheel and exert effect on the oil flow to the control device. Farm usually works in the field of husbandry. The size of the parcels is especially unsuitable for utilization of machines for big procedures, whilst the fragmentation of parcels is mostly reflected in the fuel consumption increase and lessened time for pure labour in the field.These devices, according to the manufacturer data, have lessened input costs and contributed to work being done much faster in a more quality way. With a simple selection of the Tasks option, it is possible to gain information about every field and tool that is being used but it is also possible to build an entirely new field and select new tools that encompass different kind of procedures. Touring around the field, coming to the starting point and pressing the Pen option, the field borders are going to connect into a field. From there on, one can pick the Line Management option which shows in what kind of lines can the soil be processed: parallel, concentric, curved or with premade traces. On agricultural surfaces with flat, square-shaped field borders it is best to use the parallel option. On surfaces with curved field borders, it is best to utilize the curved aggregate handling lines. Concentric lines of aggregate handling can be applied on fields that do not have a rectangular shape. Additional options which this system provides, and which are concerning the use of raw materials, are manifested in the use of technology of the automated section control. During this kind of operation, the dispensing devices of each individual section of machines turn themselves off in the case of overlapping. It is important to note that section control largely contributes to environment protection as well. The Auto Steering device for automatic control enables a secure automatic control of a driving machine in the way that the system recognizes the necessary corrections in the trajectory and steers the wheel of the machine on its own with the help of an electromotor.

\section{RESEARCH RESULTS}

Through the installation and a carried out research of the navigation device Farmnavigator, as well as surveying the owner about his farm, the following was acquired: soil sampling and analysis are conducted every 3 - 4 years. The farm has at its disposal a sufficient number of tractors and linking machines for various procedures of basic and additional soil processing. Large number of smaller parcels is today's problem of many farms. On the farm, fertilization is carried out with centrifugal fertilizers with the additional use of a navigational device along with manual handling of a tractor in order to decrease overlapping. Aggregate managing is not habitually performed along the longer side of the field, which could enable a smaller number of turns on the headlands.

Table 3 Calculation of overlap surface during driving machine without navigation

\begin{tabular}{|c|c|c|c|c|c|c|c|c|c|c|c|c|c|c|}
\hline Operations & $N$ & $N^{\prime}$ & $L_{2}$ & $L_{1}$ & $x$ & $x^{\prime}$ & $p^{\prime}$ & $p^{\prime \prime}$ & $S_{N^{\prime}}$ & $S_{\mathrm{p}^{\prime}}$ & $S_{\mathrm{p}^{\prime \prime}}$ & $S_{\mathrm{u}}$ & $S_{\mathrm{pp}}$ & $L_{\mathrm{PD}}$ \\
\hline Disc harrow/Spike harrow & 49 & 48 & 178,56 & 4,01 & 0,01 & - & 0,27 & - & 2199,43 & 45,13 & - & 102,20 & 2346,70 & - \\
\hline Soil loosener & 66 & 65 & 181,35 & 1,22 & - & 1,78 & 1,99 & - & 2298,11 & 340,2 & - & 76,68 & 2715,00 & - \\
\hline Seed harrow & 35 & 34 & 177,14 & 5,43 & - & 0,17 & 0,56 & - & 2071,43 & 90,13 & - & 142,40 & 2303,90 & - \\
\hline Sprinkler & 11 & 10 & 167,40 & 15,17 & - & 2,83 & 4,09 & 0,09 & 2070,34 & - & 16,40 & - & 2086,70 & 13,90 \\
\hline Fertilizer & 11 & 10 & 167,40 & 15,10 & - & 2,83 & 4,09 & - & 2070,34 & 746,70 & - & - & 2817,00 & - \\
\hline
\end{tabular}

Table 4 Calculation of overlap surface during driving machine with navigation

\begin{tabular}{|c|c|c|c|c|c|c|c|c|c|c|c|c|c|}
\hline Operations & $N$ & $N$ & $L_{2}$ & $L_{1}$ & $x^{\prime}$ & $p^{\prime}$ & $p^{\prime \prime}$ & $S_{N^{\prime}}$ & $S_{\mathrm{p}^{\prime}}$ & $S_{\mathrm{p}^{\prime \prime}}$ & $S_{\mathrm{u}}$ & $S_{\mathrm{pp}}$ & $L_{\mathrm{PD}}$ \\
\hline Disc harrow/Spike harrow & 48 & 47 & 178,60 & 3,97 & 0,03 & 0,23 & - & 1536,12 & 38,40 & - & 73,03 & 1647,56 & - \\
\hline Soil loosener & 66 & 65 & 182,00 & 0,57 & 2,43 & 2,63 & - & 2188,42 & 449,65 & - & 73,03 & 2711,10 & - \\
\hline Seed harrow & 34 & 33 & 178,20 & 4,37 & 1,23 & 1,43 & - & 1027,65 & 229,62 & - & 73,03 & 1330,29 & - \\
\hline Sprinkler & 11 & 10 & 178,00 & 4,57 & 13,43 & 13,63 & 0,13 & 328,63 & - & 23,73 & - & 352,36 & 4,37 \\
\hline Fertilizer & 11 & 10 & 178,00 & 4,57 & 13,43 & 13,63 & 4,63 & 328,63 & - & 845,29 & - & 1173,93 & 4,37 \\
\hline
\end{tabular}

Legend: $N$ - Total number of passages, $N^{\prime}$ - Required number of passages, $L_{2}$ - Total passage width, $L_{1}-$ Width value of the remaining part of the field intended for processing, $x$ - Difference between $L_{1}$ and $B$ length values $\left(L_{1}>B\right), x^{\prime}-$ Difference between $L_{1}$ and $B$ length values $\left(L_{1}<B\right), p^{\prime}-$ Overlap $\left(L_{1}>B\right)$, $S_{N^{\prime}}$ - Total overlap surface, $S_{\mathrm{p}^{\prime}}-$ Overlap surface (embedding of the last and the second last overlap), $S_{\mathrm{p}^{\prime \prime}}-$ Overlap width, $S_{\mathrm{u}}-$ Overlap surface (on headlands), $S_{\mathrm{pp}}$ - Total overlap surface, $L_{\mathrm{PD}}-$ The remaining width of the field intended for processing, $p^{\prime \prime}-$ Overlap $\left(L_{1}<B\right)$.

Advantage of the navigational device is the fact that it enables agricultural work during the night when the airflows are weaker (spraying and other procedures) which can have an effect on the decrease of the drift of drops during application and on better utilization of work hours and machinery efficiency [12]. The most important effect of the utilization of the navigational device manifested itself in the proper embedding of passages. The device 
showed particularly useful in situations where a certain procedure was not executed all the way to the end in the field therefore it was necessary to locate the exact position in the field in order to continue working the next day.
Total difference in the amount of overlaps during the processing of an average parcel, that ocurred during manual driving machine handling both with and without navigation, is shown in Tab. 5 .

Table 5 Difference in the amount of overlaps during average parcel processing

\begin{tabular}{|l|c|c|c|c|}
\hline \multirow{2}{*}{ Area average plot, 3,33 ha } & \multicolumn{2}{|c|}{ Manual driving machine handling } & \multicolumn{2}{c|}{ Handling with navigation } \\
\cline { 2 - 5 } & Overlap width, $\mathrm{m}$ & Total overlap surface, $\mathrm{m}^{2}$ & Overlap width, $\mathrm{m}$ & \multicolumn{2}{c}{ Total overlap surface, $\mathrm{m}^{2}$} \\
\hline Disc harrow & 0,28 & 2346,795 & 0,20 & 1647,555 \\
\hline Spike harrow & 0,28 & 2346,795 & 0,20 & 0,20 \\
\hline Soil loosener & 0,21 & 2715,055 & 0,20 & 27,555 \\
\hline Seed harrow & 0,39 & 2303,964 & 0,20 & 13,095 \\
\hline Sprinkler & 1,26 & 2086,775 & 0,20 & 352,360 \\
\hline Fertilizer & 1,26 & 2817,056 & 1173,925 & \\
\hline
\end{tabular}

\subsection{Overlap Surface during the Production of Specific Crops}

Wheat and barley - total surface of the farm on which the production of wheat and barley takes place: 350 ha ( $70 \%$ of the total surface of the farm). Number of average parcels containing wheat and barley: 105. Used agricultural mechanization and amount of utlilized connection equipment: disc harrow 2 times, seed harrows, fertilizer 4 times as well as the sprinkler. Manual handling of a driving machine without a navigational device: disc harrow (2 times) - processed surface of 700 ha. Total overlap surface on 350 ha is calculated by multiplying 105 average parcels of wheat and barley with the overlap surface during manual guidance without navigation on an average parcel and it equals:

$105 \times 2346,79 \mathrm{~m}^{2}=246413,47 \mathrm{~m}^{2}$

Since the disc harrowing operation is performed 2 times, that is, 700 ha is actually processed, the total surface of the overlap amounts to:

$$
246413,47 \mathrm{~m}^{2} \times 2=492826,95 \mathrm{~m}^{2}=49,28 \mathrm{ha}
$$

Seed harrow - processed surface of 350 ha. Total overlap surface on a 350 ha area is calculated by multiplying 105 average parcels of wheat and barley with the surface of overlaps that occur during manual guidance without navigation on an average parcel and it equals:

$$
\begin{aligned}
& 105 \times 1330,29 \mathrm{~m}^{2}=139680,55 \mathrm{~m}^{2}=13,96 \text { ha } \\
& 105 \times 2303,96 \mathrm{~m}^{2}=241916,22 \mathrm{~m}^{2}=24,19 \text { ha }
\end{aligned}
$$

Mineral fertilizer (4 times) - processed surface area of 1 400 ha. Total overlap surface on a 350 ha area is calculated by multiplying 105 average parcels of wheat and barley with the surface of overlaps that occur during manual guidance without navigation on an average parcel and it equals:

$$
105 \times 2817,05 \mathrm{~m}^{2}=295790,88 \mathrm{~m}^{2}=29,57 \mathrm{ha}
$$

Since the fertilizer is being used 4 times, i.e. 1400 ha of land is processed, the total surface of the overlap amounts to:

$$
4 \times 295790,88 \mathrm{~m}^{2}=1183,16 \mathrm{~m}^{2}=118,31 \text { ha }
$$

Sprinkler (4 times) - processed surface is 1400 ha. Total overlap surface on a 350 ha area is calculated by multiplying 105 average parcels of wheat and barley with the surface of overlaps that occur during manual guidance without navigation on an average parcel and it equals:

$105 \times 2086,77 \mathrm{~m}^{2}=219111,37 \mathrm{~m}^{2}=21,91 \mathrm{ha}$

Since the sprinkler is being used 4 times, i.e. 1400 ha of land is processed, the total surface of the overlap amounts to:

$$
4 \times 219111,37 \mathrm{~m}^{2}=876445,50 \mathrm{~m}^{2}=87,64 \text { ha }
$$

Manual aggregate handling with the help of navigation: Disc harrow ( 2 times) - processed surface of 700 ha. Total overlap surface on a 350 ha area is calculated by multiplying 105 average sized parcels of wheat and barley with the surface of overlaps that occur during manual guidance without navigation on an average parcel and it equals:

$$
105 \times 1647,55 \mathrm{~m}^{2}=172993,28 \mathrm{~m}^{2}=17,29 \text { ha }
$$

Since the disc harrowing operation is done twice, that is, the processed area is 700 ha, the total surface of the overlap amounts to:

$$
2 \times 172993,28 \mathrm{~m}^{2}=345986,56 \mathrm{~m}^{2}=34,59 \text { ha }
$$

Mineral fertilizer (4 times) - processed surface is 1400 ha. Total overlap surface on a 350 ha area is calculated by multiplying 105 average parcels of wheat and barley with the surface of overlaps that occur during manual guidance without navigation on an average parcel and it equals:

$$
105 \times 1173,92 \mathrm{~m}^{2}=123262,12 \mathrm{~m}^{2}=12,32 \text { ha }
$$

Since the fertilizer is being used 4 times, i.e. 1400 ha of land is processed, the total surface of the overlap amounts to:

$$
4 \times 123262,12 \mathrm{~m}^{2}=493048,50 \mathrm{~m}^{2}=49,30 \text { ha }
$$


Sprinkler (4 times) - processed surface is 1400 ha. Total overlap surface on a 350 ha area is calculated by multiplying 105 average parcels of wheat and barley with the surface of overlaps that occur during manual guidance without navigation on an average parcel and it equals:

$$
105 \times 352,36 \mathrm{~m}^{2}=36997,80 \mathrm{~m}^{2}=3,69 \text { ha }
$$

Since the sprinkler is being used 4 times, i.e. 1400 ha of land is processed, the total surface of the overlap amounts to:

$$
4 \times 36997,80 \mathrm{~m}^{2}=147991,20 \mathrm{~m}^{2}=14,79 \text { ha }
$$

Tab. 6 shows that the difference between the amount of overlaps during manual guidance of the machine and the navigational guidance is 166,78 ha.

Corn - surface of the farm on which the production of corn takes place: 50 ha $(10 \%$ of the total surface of the farm). 15 average parcels containing corn. Used agricultural mechanization and amount of utlilized connection equipment are visible in Tab. 5. Equivalently with the display of the calculation of wheat and barley production, the calculation for the amount of overlap during corn production was derived. Tab. 7 shows that the difference between the amount of overlaps during manual guidance of the machine and the navigational guidance is 11,08 ha.

Table 6 Values of the amount of overlaps during the production of wheat and barley

\begin{tabular}{|l|c|c|c|}
\hline \multirow{2}{*}{\multicolumn{1}{|c|}{ Wheat and barley, 350 ha }} & Processed surface (ha) & Manual handling & \multicolumn{2}{c|}{ Overlap surface (ha) } \\
\cline { 3 - 4 } & & 49,28 & 24,19 \\
\hline Disc harrow & 350 & 87,64 & 34,57 \\
\hline Seed harrow & 1400 & 118,31 & 13,96 \\
\hline Sprayer $(4 \times)$ & 1400 & 279,43 & 14,79 \\
\hline Fertilizer $(4 \times)$ & 3850 & & 49,30 \\
\hline Total & & & 112,65 \\
\hline Calculated difference & & & 166,78 \\
\hline
\end{tabular}

\begin{tabular}{|c|c|c|c|}
\hline \multirow{2}{*}{ Corn, 50 ha } & \multirow{2}{*}{ Processed surface(ha) } & \multicolumn{2}{|c|}{ Overlap surface (ha) } \\
\hline & & Manual handling & Handling with navigation \\
\hline Disc harrow & 50 & 3,52 & 2,47 \\
\hline Spike harrow & 50 & 3,52 & 2,47 \\
\hline Seed harrow & 50 & 3,45 & 1,99 \\
\hline Sprayer & 50 & 3,13 & 0,52 \\
\hline Fertilizer $(2 \times)$ & 100 & 8,45 & 3,52 \\
\hline Total & 300 & 22,07 & 10,98 \\
\hline Calculated difference & & & 11,08 \\
\hline
\end{tabular}

Table 7 Values of the amount of overlaps during the production of corn

\begin{tabular}{|c|c|c|c|}
\hline \multirow{2}{*}{ Oilseed rape, 50 ha } & \multirow{2}{*}{ Processed surface(ha) } & \multicolumn{2}{|c|}{ Overlap surface (ha) } \\
\hline & & Manual handling & Handling with navigation \\
\hline Soil loosener & 50 & 4,07 & 4,06 \\
\hline Disc harrow & 50 & 3,52 & 2,47 \\
\hline Seed harrow & 50 & 3,45 & 1,99 \\
\hline Sprayer $(3 \times)$ & 150 & 9,39 & 1,58 \\
\hline Fertilizer $(4 \times)$ & 200 & 16,90 & 7,04 \\
\hline Total & 500 & 37,34 & 17,16 \\
\hline Calculated difference & & & 20,17 \\
\hline
\end{tabular}

Table 8 Values of the amount of overlaps during the production of oilseed rape

Table 9 Values of the amount of overlaps during the production of sunflower

\begin{tabular}{|l|c|c|c|}
\hline \multirow{2}{*}{ Sunflower, 50 ha } & Processed surface(ha) & \multicolumn{2}{c|}{ Overlap surface (ha) } \\
\cline { 2 - 4 } & & Manual handling & 3,52 \\
\hline Spike harrow & 50 & 3,52 & 2,47 \\
\hline Disc harrow & 50 & 3,45 & 2,47 \\
\hline Seed harrow & 50 & 6,26 & 1,99 \\
\hline Sprayer $(2 \times)$ & 100 & 25,45 & 3,05 \\
\hline Fertilizer $(2 \times)$ & 100 & 3,52 & 11,51 \\
\hline Total & 350 & & 13,69 \\
\hline Calculated difference & & & \\
\hline
\end{tabular}

Oilseed rape - surface of the farm on which the production of rapeseed takes place: 50 ha $(10 \%$ of the total surface of the farm). 15 average parcels containing rapeseed. Used agricultural mechanization and amount of utlilized connection equipment are visible in Tab. 8. Equivalently with the display of the calculation of previous crops production, the calculation for the amount of overlap during rapeseed production was derived.

Tab. 8 shows that the difference between the amount of overlaps during manual guidance of the machine and the navigational guidance is 20,17 ha.
Sunflower - farm has production of sunflower of 50 ha ( $10 \%$ of the total surface of the farm). 15 average parcels containing sunflower. Used agricultural mechanization and amount of utlilized connection equipment are visible in table 9. Equivalently with the display of the calculation of previous crops production, the calculation for the amount of overlap during rapeseed production was derived.

Tab. 9 shows that the difference between the amount of overlaps during manual guidance of the machine and the navigational guidance is $13,69 \mathrm{ha}$. The amount of overlaps at total production of all crops on the farm is presented in 
Tab. 10 in which there is a total number of agricultural operations and amounts of overlaps that occur during these operations.

Tab. 10 shows that the difference between the amount of overlaps during manual guidance of the machine and the navigational guidance is 211,74 ha. The total results show that the farm, in all operations processes a total surface of 5364,06 ha is being lost on overlaps during machinery operation without information presented to the handler with the help of a navigational device screen. By utilizing the navigational system and reducing overlaps in observed operations on mere $20 \mathrm{~cm}$, there is a bigger use of the work procedure of the machines, which in turn results with a lesser number of overlaps and finally a decrease of the total overlap surface that occur during operation at the amount of 211,743 ha. Certainly, these pieces of information were gathered through generalization of certain important factors that have a direct effect on the calculation of overlap surface, such as using the value of an average parcel surface or mean values during calculations of work procedure utilization etc.

Table 10 Total overlap amount during production on the farm

\begin{tabular}{|l|c|c|c|}
\hline \multicolumn{1}{|c|}{ All crops, 500 ha } & Processed surface(ha) & \multicolumn{2}{c|}{ Overlap surface (ha) } \\
\cline { 2 - 4 } & & Manual handling & Handling with navigation \\
\hline Spike harrow & 100 & 5,04 & 4,84 \\
\hline Disc harrow & 850 & 4,07 & 41,99 \\
\hline Soil loosener & 50 & 34,56 & 106 \\
\hline Seed harrow & 500 & 106,42 & 19,95 \\
\hline Sprayer & 1700 & 152,12 & 63,39 \\
\hline Fertilizer & 1800 & 364,06 & 152,32 \\
\hline Total & 5000 & & \\
\hline Calculated difference & & & \\
\hline
\end{tabular}

Rationalization of production, proper machine handling during fieldwork (passages on the longer side of the field) and utilization of machines for smaller work procedures (smaller rotation radius, rotation in one procedure) on smaller parcels should all affect the improvement of the utilization structure of work hours. The sole application of the navigational device was directly reflected in the decrease of passage overlap, that is, a more precise embedding of aggregate passages, which in turn decreased a certain number of passages during soil processing.

In order to use the navigational device to the best of its possibilities, it is important to invest additional capital funds so that the system could be equipped with an automatic section control, which would reduce overlapping to a minimum. Automatic section control demands additional investments in devices that control the work of section.

\section{CONCLUSION}

The analysis of the navigational device and the analysis of the state of the farm gave a conclusion of how the use of navigational technologies is indispensable for quality agricultural procedures, rationalization of consumption and a better record of executed field operations. The level of investment should be based on the findings of field characteristics and data collected through regular soil analyses. Larger manufacturers have the possiblities and the need to introduce new technologies to a greater extent considering they mostly process large agricultural surfaces where losses but also savings are massive. On these kinds of surfaces, it is possible to apply most of the precise agriculture procedures as well as informational and navigational technologies. Smaller farms which are characterized by larger fragmentation of property are not able (mostly because of economical restrictions) to apply high, mostly expensive, technology because of the much longer profitability of these precise agriculture systems. On family farms such as presented, processed through work, it is best to apply measures of rational production with good handling strategies and soil analysis as well as the use of navigational technologies as an important element that betters the record of carried out operations and ensures certain savings that exhibit themselves through a more rational utilization of agricultural raw materials. The unburdening of the handler, both physical and mental, shows a great positive effect, especially during automatic control of an agricultural machine. Automatic control brings certain savings and unburdening of the operator but it is almost useless if it is not completed with the newest technologies of precise agriculture and additional investment in precise correctional signals purchase.

\section{REFERENCES}

[1] Jurišić, M. \& Plaščak, I. (2009). Geoinformacijski sustavi GIS u poljoprivredi i zaštiti okoliša, Poljoprivredni fakultet Osijek, Osijek.

[2] Crneković, M. (2015). Automatsko vođenje traktora, strojeva $i$ uređaja u sustavu GIS-precizna poljoprivreda, Poljoprivredni fakultet Osijek, Osijek.

[3] Zimmer, D., Jurišić, M., Plaščak, I., \& Barač, Ž. (2016). Tehnčki i tehnološki čimbenici gnojidbe primjenom GIS tehnologije u poljoprivredi. Agronomski glasnik, 78(1), 2740.

[4] Stracenski, S. (2015). Automatsko vođenje poljoprivrednih strojeva te gnojidba šećerne repe u sustavu precizne poljoprivrede, Poljoprivredni fakultet Osijek, Osijek.

[5] Brkić, D., Vujčić, M., Šumanovac, L., Lukač, P., Kiš, D., Jurić, T., \& Knežević, D. (2005). Eksploatacija poljoprivrednih strojeva, Poljoprivredni fakultet Osijek, Osijek.

[6] Stević, A. (2014). Primjena GIS tehnologije u sustavu precizne poljoprivrede pri sadnji trajnih nasada, Poljoprivredni fakultet Osijek, Osijek.

[7] Banaj, Đ. \& Šmrčković, P. (2003). Upravljanje poljoprivrednom tehnikom, Poljoprivredni fakultet Osijek, Osijek.

[8] Kuskunović, M. (2016). Dronovi snimaju njive i spremaju podatke za početak precizne sjetve. http://www.agrobiz.hr/ agrovijesti/dronovi-snimaju-njive-i-spremaju-podatke-zapocetak-precizne-sjetve-847 (Accessed on 10.02.2017) 
[9] Grgić, K. (2015). Primjena precizne gnojidbe u ratarstvu koncerna Agrokor. 51. Hrvatski i 11. Međunarodni simpozij poljoprivrede, Opatija, Hrvatska.

[10] Pavlović, N. (2015). Tehničko-tehnološki činitelji sjetve $i$ sadnje primjenom GIS tehnologije - precizna poljoprivreda, Poljoprivredni fakultet Osijek, Osijek.

[11] Marković D, i dr. (2011). Analiza ekonomskih pokazatelja u primeni gps tehnologije u poljoprivrednom kombinatu Beograd. Savremena poljoprivredna tehnika, 37(3), 283294.

[12] Schnug, E., Lilienthal, H., Panten, K., \& Haneklaus, S. (2003). Smart Navigation-Salvation for Precision Agriculture, In Proceeding of $11^{\text {th }}$ IAIN World Congress.

\section{Contact information:}

Mladen JURIŠIĆ, PhD, Full Professor

Faculty of Agriculture

Vladimira Preloga 1, 31000 Osijek, Croatia

mjurisic@pfos.hr

Ivan PLAŠČAK, PhD, Assistant Professor

Faculty of Agriculture

Vladimira Preloga 1, 31000 Osijek, Croatia

iplascak@pfos.hr

Domagoj ZIMMER, MSc, Assistant

Faculty of Agriculture

Vladimira Preloga 1, 31000 Osijek, Croatia

dzimmer@pfos.hr

Željko BARAČ, MSc, Assistant

Faculty of Agriculture

Vladimira Preloga 1, 31000 Osijek, Croatia

zbarac@pfos.hr

Irena RAPČAN, PhD, Assoc. Professor

Faculty of Agriculture

Vladimira Preloga 1, 31000 Osijek, Croatia

irapcan@pfos.hr 